\title{
A saia de Marilyn: do arquétipo ao estereótipo nas imagens midiáticas
}

\section{Ana Taís Martins Portanova Barros}

\section{Resumo}

Este artigo desenvolve uma reflexão sobre a natureza do estereótipo nas imagens iconográficas midiáticas com o objetivo de mostrar de que modo elas se relacionam com os níveis mais profundos do imaginário: os arquétipos e os mitos. Utiliza-se a classificação dos regimes do olhar feita por Régis Debray e os pressupostos dos estudos do imaginário de Gilbert Durand, demonstrando-se que o estereótipo é o ponto culminante de um processo de empobrecimento simbólico. Tal empobrecimento ocorre através da desmitologização de mitos que, originalmente, têm papel contestatório e libertador nas sociedades. Por fim, utiliza-se o método da mitocrítica durandiana para se analisarem quatro imagens midiáticas que permanecem ativas na memória coletiva. Conclui-se que na sua base elas remetem a mitos importantes para a equilibração psicossocial, mas que foram degradados por sua institucionalização na mídia, resultando na estereotipia de imagens que derivam de arquétipos da feminilidade, da queda, do trickster e do herói.

Palavras-chave

Imagem. Mito. Estereótipo. Mídia.

Ana Taís Martins Portanova Barros I ana.tais@ufrgs.br

Doutora em Ciências da Comunicação pela Escola de Comunicações e Artes da Universidade de São Paulo - USP. Professora do Departamento de Comunicação da Faculdade de Biblioteconomia e Comunicação da Universidade Federal do Rio Grande do Sul - UFRGS.

\section{Introdução}

A avalanche de imagens que se observa hoje, resultante do constante incremento das tecnologias, traz para o cotidiano uma pletora de símbolos, estereótipos e preconceitos em forma visual. A banalização da presença de imagens visuais sugere um esvaziamento de sua significação, ou seja, de sua pregnância simbólica. Sodré fala mesmo em uma forma tecnológica de nominalismo, peculiar à mídia eletrônica, "onde importa mais a conexão do que o sentido" (SODRÉ, 2002, p. 246). Significação eliminada, resta apenas o signo e seu referente.

Há, pois, um transbordamento de imagens que impede sua assimilação. Não é mais necessário ver; basta visualizar. No regime visual, Debray (1993) ensina que a imagem não vê nem é vista, e sim percebida. Se outrora houve modos de existência da imagem em que ela é que via, era presença protetora (regime do ídolo, logo após 0 advento da escrita), passando depois a ser vista, a proporcionar deleite ao seu espectador (regime da arte, após a chegada da imprensa), hoje estamos na imagem; temos a visão, mas não 
o olhar. Da eternidade apresentada pelo ídolo, deslizamos à imortalidade representada pela arte e chegamos à atualidade simulada.

0 objeto da visualização transmuta-se em aparição no que ela tem de efêmera; não chega a marcar a consciência porque é rapidamente substituída por outra aparição. As imagens desfilam, assim, numa sucessão de flashes. Quem vê tudo, afinal, não vê nada.

Não que essas imagens tão fartamente disponibilizadas pela mídia sejam vazias de sentido em si, mas sua quantidade avassaladora e a rapidez de suas aparições, associadas à aceleração do tempo pessoal dos sujeitos resulta num processo em que não há tempo-espaço para a simbolização. É possível afirmar que a visualização pede um estereótipo, espécie de anti-símbolo: por apresentar o já pensado, dispensa a simbolização. No entanto, os estudos do imaginário, especialmente os da Escola de Grenoble, mostram como a imagem nasce num fértil subsolo arquetípico, torna-se consciente em símbolos, mitos e, possivelmente, estereótipos, numa escala que vai da máxima pregnância simbólica ao seu esvaziamento total, restando, na camada mais enrijecida dessa arqueologia, uma imagem já-dita que fere a ética (o preconceito). Se 0 arquétipo relativiza pressão dos códigos culturais (PAULA CARVALHO, 1985, p.733), o estereótipo os endossa.

A noção de arquétipo com que se trabalha aqui é aquela dos estudos do imaginário que, por sua vez, assimila Jung: conteúdos do inconsciente coletivo, imagens primordiais e universais. Diz Jung: "As imagens arquetípicas são a priori tão significativas que 0 homem nunca pergunta o que, a rigor, poderiam significar" (JUNG, 1991, p. 19). Arquétipos seriam conteúdos psíquicos não submetidos a nenhuma espécie de elaboração consciente.

Durand sublinha a universalidade constante dos arquétipos, sua estabilidade em contraste com a diversidade dos símbolos, que variam enormemente de acordo com o meio. Assim, enquanto "o arquétipo do céu permanece imutável, o simbolismo que o demarca transformase de escada em flecha voadora, em avião supersônico ou em campeão de salto" (DURAND, 1998, p. 62). Observa-se, na passagem do arquétipo ao símbolo, uma primeira multiplicação de derivações da imagem primordial e, ao mesmo tempo, um certo estreitamento de sua simbolização, ocasionado pela adequação a concretudes históricas, sociais, culturais.

0 nível seguinte seria 0 mito, narrativa que organiza imagens simbólicas e arquetípicas: "0 mito é já um esboço de racionalização, dado que utiliza o fio do discurso, no qual os símbolos se resolvem em palavras e os arquétipos em ideias" (DURAND, 1998, p. 63). Adiante serão mostrados alguns casos dessa relação entre arquétipo, mito e estereótipo.

A essa altura, é pertinente perguntar de que modo o mito, que se manifesta sabidamente 
por meio do discurso, terá relação com a estereotipia de imagens midiáticas. Ocorre que a imagem iconográfica - assim designada a fim de não ser confundida com a imagem que é, simplesmente, produto direto da imaginação e que, por sua capacidade de atribuir sentido ao mundo pode ser também chamada de imagem simbólica - é vista e compreendida, ela também, como parte de um discurso. Não se trata, é claro, do discurso físico, um texto dito ou falado, mas de um discurso ativo na ambiência de dada sociedade, constituinte de seu imaginário.

\section{Do arquétipo ao estereótipo através da desmitologização}

Para entender como uma imagem plena de pregnância simbólica degrada-se até chegar ao estereótipo, será útil recorrer à noção de tópica sociocultural apresentada por Durand em seus estudos: há sempre um, dois ou mesmo três mitos circulantes nas sociedades, mitos como os de Prometeu, Hermes e Dionísio, por exemplo, que vitalizam essas sociedades e lhes dão sentido. De tempos em tempos, o mito que estava no apogeu entra em decadência, dando espaço a outro, que subsistia na marginalidade.

Os mitos circulam entre vários níveis do imaginário. 0 primeiro é um nível fundador, arquetípico, chamado por Durand de isso, o inconsciente antropológico. 0 nível seguinte é o ego societal, também chamado de actancial por ser ele o palco dos atores sociais. Aqui se encontram dois pólos, um positivo - com os papéis confortados pela ideologia vigente - e outro negativo - com os papéis e funções marginalizadas. Acima desses dois níveis, vem o superego societal, a imagem racionalizada de uma sociedade, defendida pelas pedagogias, pelas instituições, pelos programas e localizada, a partir do século XX, nos meios de comunicação.

Ao circular por todos esses lugares, certos aspectos do mito são marginalizados, outros são reforçados até 0 ponto de serem institucionalizados e sentidos como naturais, mais ou menos de acordo com o processo de naturalização da história denunciado por Barthes (1999) como sendo constitutivo do mito. A principal diferença entre a noção de mito em Barthes e em Durand é, talvez, essa: enquanto 0 segundo vê 0 enrijecimento do mito como uma das fases de seu ciclo vital, o primeiro não reconhece seu papel organizador e equilibrante, concentrando-se no seu momento perverso.

0 mito, ao circular numa sociedade, vitalizando-a, acaba também se transformando e se degradando, num processo de usura (DURAND, 1996, p. 176). É assim que imagens míticas, inicialmente fortes, com alta capacidade de suscitar a simbolização, perdem alguns de seus aspectos, têm outros desmesuradamente reforçados, outros, ainda, substituídos até que, ao final, não reste muito do mito original. Postulamos que nesse processo ocorre também o nascimento dos estereótipos. Falamos, especialmente, dos estereótipos na 
mídia, posto que é através das comunicações que, hoje, o mito se institucionaliza e perde seu aspecto selvagem e contestatório (DURAND, 1996, p. 155). 0 mesmo autor afirma:

Estamos [...] na presença de três níveis míticos simultâneos, onde um data pelo menos do último século - 0 das nossas pedagogias -, onde 0 outro consiste em uma liberação sustentada pelos enormes meios tecnológicos, estupefacientes, espirituais e visuais que distribuem as mídias e que permitem suportar as monotonias da vida tecnocrática e burocrática que nos ensinaram nossas escolas. Enfim, 'na solidão da razão', como escrevia Ferdinand Alquié, mas de uma outra razão, mais solitária, existem sábios que perceberam, sem se conhecerem uns aos outros, que eles estão reencontrando mitologias negligenciadas ou esquecidas, que eles constroem, à Princeton ou por aí, a Gnose de nossa modernidade... (DURAND, 2004, p. 19-20).

Ou seja, contemporaneamente, viveríamos, ainda, sob o mito de Prometeu, com toda sua valorização do auto-sacrifício em busca do conhecimento, presente nas nossas pedagogias.

A ciência já sente a influência de Hermes, ao recusar sempre mais as regras de exclusão do tipo hipotético-dedutivo, ao admitir a coincidentia oppositorum, ao incluir um terceiro, negando a lógica dualista. Hermes, no entanto, estaria ainda em estado germinal. Já as comunicações são presididas incontornavelmente por Dionísio, não somente com a óbvia escalada do orgiasmo na programação televisiva, mas sobretudo com um ideário do viver agora, do viver bem, dos resultados rápidos e imediatos, ideário esse que se contrapõe ao de Prometeu.

\section{Dionísio e a mídia}

Relembremos o mito de Dionísio: filho de

Perséfone, a rainha do mundo subterrâneo, e

Zeus, é dilacerado e devorado pelos titãs, só dando tempo a Atena de resgatar seu coração, que o pai come. Depois, Zeus fulmina os titãs. Das cinzas deles, nascem os homens, que contêm em si uma parte divina, vinda de Dionísio, e uma parte oposta, vinda dos titãs. Dionísio renasce da conjunção de Zeus com Sêmele.

Os rituais dionisíacos, como os das mênades, mostram Dionísio enlouquecendo as pessoas e também libertando-as da loucura. (LÓPEZPEDRAZA, 2002, p. 31). Nesse caso, a loucura é uma experiência a partir da qual é possível 0 renascimento. Se Dionísio - "deus em oposição aos titãs; 0 deus das emoções; 0 deus mais reprimido da cultura ocidental; o deus das mulheres, do vinho, da tragédia e o deus que possui uma forte conexão com a morte" (LÓPEZPEDRAZA, 2002, p. 9)- estivesse presente nas comunicações com toda sua integridade, toda sua força criadora e contestatória, poderíamos caracterizar as comunicações como um fator de equilibração psicossocial, que permite ao homem individual a introspecção, entrando em contato com seu subsolo arquetípico, se autoexaminando e reelaborando sua existência. No entanto, um mito, ao chegar ao ponto de se institucionalizar, como ocorre com Dionísio na mídia, passou por um processo de enrijecimento, de absolutização de certos aspectos e de 
dissolução de outros, de modo a perder seu equilíbrio e coesão internos. Nesse ponto, como diz Durand (1996), o mito carrega um nome que não é seu.

Podemos dizer que a mídia, talvez para domar as forças dionisíacas, reprime boa parte do mesmo mito. Tomemos o exemplo sempre disponível da imagem televisiva:

A imagem, por sua sucessão rápida na superfície da tela, entranha, com efeito, excitações visuais e psíquicas, em altas frequências e densidade, que instalam o sujeito espectador em um estado quase cataléptico. 0 desfile das imagens aprisiona a atenção, atenua 0 umbral de vigilância do mundo e instala a consciência em uma espécie de fascinação exclusiva (WUNENBURGER, 2005, p. 29).

No seguimento da análise, Wunenburger

apresenta 0 espectador como um possuído que renunciou a identificar, a julgar, a avaliar cada uma das solicitações propostas pela tevê. Se é possível identificar aqui uma importante ação de Dionísio, aquela que leva o sujeito a um estado de embriaguez, falta a respectiva viagem interior que promoveria a contraparte da loucura: a libertação e a recriação de si. Não será por acaso que justamente a conexão que Dionísio nos insta a fazer com nosso ser mais profundo é banida quando de seu comparecimento na mídia.

Durand nos dá pistas para entender a imperiosidade da repressão desse aspecto do mito de Dionísio nos nossos tempos ao opor duas visões do homem. Uma, a chamada tradicional, figurada por homens que, de acordo com a psicanálise, a etnologia psicológica e a psicologia das profundezas são providos dos mesmos desejos, das mesmas estruturas afetivas e para quem as mesmas imagens (simbólicas) "se propagam tanto no espaço como no tempo, de um extremo a outro da humanidade" (DURAND, 2008, p. 15). Outra, figurada pelo homem ocidental, o homem filosófico, que busca o progresso do saber e luta contra os obscurantismos, dissociando cultura e natureza. Para o homem da tradição, "a vida é um êxodo, um retorno. A razão de ser do homem, de seus atos assim como de seu pensamento, é a recondução para além da queda, para além da separação" enquanto "Deus, para 0 espírito filosófico, é uma ameaça externa à sabedoria totalmente humana que 0 homem, privado do intelecto divino, construiu" (DURAND, 2008, p. 53). Se considerarmos, com Durand, a ontologia do imaginário, entenderemos por que, mesmo quando as sociedades enaltecem o pensamento racional, crendo-o purgado de todos os mitos, ainda assim são mitos que a vitalizam. É por isso que temos esse Dionísio produzindo imagens nos nossos dias. Para se adequar ao superego societal, sofreu um processo de alijamento de sua potência religiosa, de sua capacidade de recondução do ser à sua essência.

E assim retornamos ao ponto de partida, ou seja: num regime de visualidade, com um Dionísio enrijecido presidindo a mídia e, por consequência, tendo-se o princípio do prazer por norma, há que se minimizar qualquer esforço. Não sobra muito espaço para imagens que nos 
protejam, como no regime ídolo; não há tempo para imagens que devem ser contempladas, como no regime arte; é possível, somente, perceber a imagem. É por isso que ela tem de ser mais e mais icônica, reduzindo suas contradições, fazendo referência ao já-dito, ao já-visto, ao já-sabido porque não há tempo nem disposição para novas sinapses. Compreensão e percepção têm de ser simultâneas, mas isso só acontece quando não há nada de novo pela frente. Eis a perfeita adequação da imagem estereotipada à contemporaneidade veloz.

Passemos, agora, a uma rápida explicação sobre o método utilizado para se determinar o mito ativo em dada obra e que será aplicado em seguida a quatro fotografias presentes na memória coletiva.

\section{A mitocrítica como método}

A mitocrítica tem o objetivo de verificar temas ou metáforas obsessivas presentes em obras da cultura em geral. Teixeira Coelho explica que "a mitocrítica procura identificar mitos pessoais e suas eventuais relações e projeções sobre os mitos coletivos com o objetivo de armarem-se grandes redes de constelações simbólicas" (COELHO, 1997, p. 253). 0 método consiste, basicamente, no recenseamento das imagens simbólicas em dado material cultural.

Relembremos que a imagem simbólica não é sinônima de imagem iconográfica, embora possa habitar essa última. Por imagem simbólica entende-se, aqui, aquela que "faz aparecer um sentido secreto" (PITTA, 2005, p. 18). Imagem, em sentido amplo, é o modo de a consciência (re)apresentar objetos que não se apresentam diretamente à sensibilidade. A reunião dessa imagem com um sentido, um aspecto vivenciado resultará num símbolo (COELHO, 1997, p. 343).

As imagens simbólicas devem ser agrupadas por convergência, que Durand define como uma homologia mais do que como uma analogia. Como metáfora dessa diferença, Durand diz que a analogia está para a arte musical da fuga assim como a convergência está para a variação temática. E completa: “[...] os símbolos constelam porque são desenvolvidos de um mesmo tema arquetipal, porque são variações sobre um arquétipo" (DURAND, 1998, p. 43). A partir das redundâncias de imagens em dado universo, busca-se 0 isomorfismo dos símbolos convergentes que remetem aos mitos diretores em ação. Assim, verificaremos, por exemplo, que a água e a cabeleira convergem com a feminilidade e a velocidade e as trevas constelam com a queda.

Em meio à pletora de imagens icônicas, rapidamente desaparecidas da memória coletiva, há algumas que, pelo contrário, nela permanecem de modo marcante, resistentes ao tempo e às circunstâncias. Reproduções delas são encontradas com relativa facilidade na mídia e, à sua simples menção verbal, elas 
surgem facilmente na mente dos sujeitos, ainda que elas datem de um momento histórico ao qual esses sujeitos são alheios, seja por sua juventude em relação à imagem em questão, seja por ignorarem 0 contexto em que essa imagem se originou.

Postulamos, como já foi referido antes, que a perda de certas características de um mito e a absolutização de outras está na raiz dos estereótipos. 0 estereótipo seria, assim, uma espécie de mito desmitologizado. Se uma imagem estereotipada tem um ancestral arquetípico e mítico, seria possível localizálo? Selecionamos quatro fotografias que estão vivamente presentes no imaginário ocidental contemporâneo para fazer a verificação através da mitocrítica.

\section{Mitocrítica de quatro imagens midiáticas}

0 senso comum já tem presente a informação de que, ao vermos anúncios, as imagens dele capturam a maior parte da nossa atenção.

Algumas das imagens difundidas pela mídia contrariam sua predisposição para a efemeridade e parecem ficar para sempre na memória coletiva tão perfeitamente presentes a ponto de o publicitário Michael Schirner, na mostra Pictures in Mind, realizada na metade dos anos 1980, ter podido simplesmente apresentar quadros pretos com legendas como "A pegada do primeiro homem na lua" ou "Albert Einstein mostrando a língua".
É fato que nossa memória guarda antes imagens paradas do que imagens em movimento.

Algumas fotografias divulgadas pela mídia alcançam a celebridade, como Uma madona dos cortiços (1911), de Lewis Hine, ou $O$ cadáver de Guevara (1967), da United Press International (UPI). Machado aventa a hipótese de que 0 impacto dessas fotografias se deva à coincidência "com certos arquétipos pictóricos que povoam o inconsciente de nossa civilização" (MACHAD0, 1984, p. 62). No caso, 0 autor comparava a composição da fotografia de Hine à da pintura Madona na cadeira, de Rafael, e a composição da fotografia de Guevara morto rodeado de militares e agentes da CIA ao Cristo morto de Mantegna ou à Lição de anatomia de Rembrandt.

As fotografias mencionadas por Machado não são tão largamente conhecidas do público a ponto de serem prontamente reconhecidas. No entanto, há pelo menos uma dúzia de fotografias que sim, são tão maciçamente divulgadas que chegaram ao senso comum. Mesmo sem apresentarem composições atávicas, essas fotografias de algum modo reverberam intensamente no imaginário ocidental a ponto de ser justo perguntar por suas raízes míticas e arquetípicas. Selecionamos quatro dessas imagens para aqui analisar. 


\subsection{Marilyn Monroe com a saia voando sobre um respiradouro do metrô de Nova York}

Figura 1: Marilyn Monroe com a saia voando sobre um respiradouro do metrô de Nova York, cena do filme 0 pecado mora ao lado (Billy Wilder, 1955).

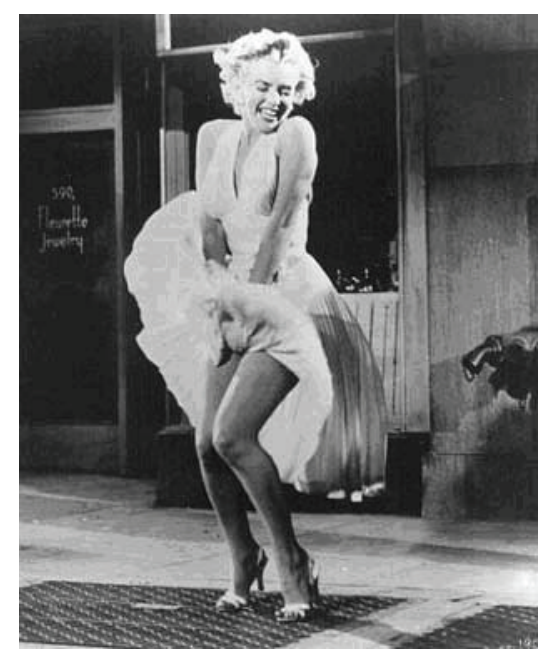

Fonte: http://www.webcine.com.br/filmessc/sevenyei.htm

Essa é uma imagem que, originalmente, está no filme $O$ pecado mora ao lado (1955), de Billy

Wilder. No entanto, a memória fotográfica da cena foi tão forte que ganhou autonomia. Temos aí a imagem da pureza safada, da inocência maliciosa: um vestido muito decotado, mas branco; seu comprimento cobriria os joelhos, mas o jato de ar do respiradouro do metrô fez com que seus panos se erguessem até a cintura, expondo uma pudica intimidade. Marilyn tenta, castamente, abaixar a saia do vestido com as mãos, mas seu amplo sorriso denuncia o quanto está se divertindo com a situação. Entre tantas fotografias de Marilyn, essa é das mais lembradas - pelo menos pelo senso comum. Isso autoriza a suposição de que há a junção do ingrediente celebridade com algum outro, inerente a esse símbolo iconográfico específico, que garante a permanência dessa cena no imaginário. A composição da cena nada tem de especial; sua força advém da tensão entre as mensagens contraditórias que ela destila.

0 vestido esvoaçante de Marilyn remete imediatamente ao arquétipo da feminilidade. A saia plissada ergue-se sob a força do vento de tal modo que se assemelha a uma concha envolvendo a atriz. Durand (1998) mostra como a imagística da água se submete ao arquétipo da mulher: a água é feminina porque acolhe, embala, fertiliza. Envolta na sua saia-concha, Marilyn é a Vênus de Boticelli emergindo do mar.

No momento histórico da realização da fotografia de Marilyn, cabelos longos e esvoaçantes não estavam na moda; os cabelos curtos da atriz não são capazes de lhe envolver o corpo, como fazem os da Vênus de Botticelli. No entanto, a saia-concha de Marilyn rodeia seu corpo num abraço que lembra a cabeleira, outra imagem do feminino. Por fim, o Zéfiro que sopra sobre Vênus, dando-lhe a vida, sopra também a saia de Marilyn, revelando sua sedução.

Para além das impressões que arrolam semelhanças iconográficas entre Vênus e a clássica imagem de Marilyn, podemos buscar em uma das derivações do mito de Vênus uma figuração da relação do espectador com a fotografia de Marilyn. Mais uma sedutora e enganadora Melusina do que uma fatal Carmen, Marilyn é a mulher maravilhosamente bela, 
desacompanhada, que parece estar à espera do homem que a encontra. No esquema melusiano, essa mulher é sobrenatural, daí a origem de sua beleza. Ela aceita desposar o homem que por ela se apaixona mediante certa interdição que, se violada, acarretará a separação do casal. Segundo Lancner, a prefiguração mais exata do mito melusiano é a seguinte versão medieval:

\begin{abstract}
Um cavaleiro encontra perto de um rio uma bela moça a cavalo, que aceita ser sua esposa desde que ele nunca a veja nua. Certo dia, entretanto, ele penetra no quarto onde a moça tomava seu banho e a vê desaparecer na água sob a forma de uma serpente. Mas os filhos continuaram junto do pai e a linhagem da fada pôde perpetuar-se até a época do narrador da história (LANCNER, 2000, p. 629).
\end{abstract}

Ora, a interdição imposta por essa e todas as Marilyns é a da própria aproximação física: imagem etérea, se tocada revelará sua natureza imaterial e, pois, inatingível. No clichê das imagens midiáticas, o mito não se realiza totalmente. Melusina desaparece após ter sido vista nua, mas deixa descendência neste mundo, garantindo a continuação da linhagem divina aqui. 0 espectador que quiser ultrapassar 0 limite imposto pela imagem de Marilyn verá seu encanto desaparecer, ela se transformará em simples folha de papel manchado de tinta ou algo assim. Entretanto, diferente de Melusina, Marilyn não povoará o mundo do espectador com frutos de uma imponderável conjunção, aquela entre 0 homem e sua dimensão transcendental. 0 salto sobre 0 abismo que os separa só será permitido se a imagem midiática estereotipada não impuser ao espectador o exílio desse além que é o mito.

\section{Marilyn lembrada repetidamente com sua} saia esvoaçante torna-se um estereótipo da feminilidade na medida em que alija o mito melusiano de seu viés libertário. A mulher divina e forte, capaz de reconduzir a humanidade à transcendência reduz-se à simples sedutora que sorri, afetadamente espantada com o suposto acidente que lhe revela as pernas.

\subsection{Um avião se chocando com as Torres Gêmeas}

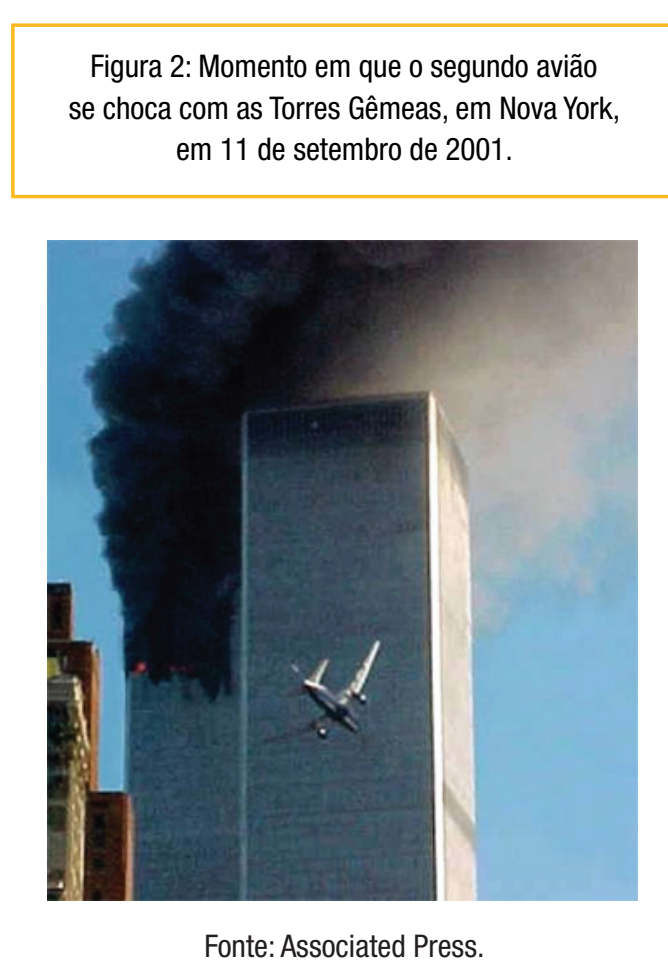

Eis uma imagem constituída basicamente por símbolos de ascensão: contra um céu azul, erguese 0 espigão de uma das duas Torres Gêmeas do World Trade Center em Nova York. Tal simbolismo transmuta-se em imagem aterrorizadora da queda 
por força da fumaça negra no quadrante superior esquerdo da imagem, que indicia a tragédia. Um avião aparece muito próximo da torre que ainda está intacta; 0 clique foi realizado segundos antes do choque que completou a destruição do edifício. Esse simbolismo ascensional, por seu viés angustiante, remete ao arquétipo da queda. Durand sublinha que "a queda resume e condensa os aspectos temíveis do tempo" (1998, p. 113). A imagem da fotografia em questão grita a apavorante proximidade da tragédia total: a destruição já começou, mas será ainda pior, pois o avião está muito perto da segunda torre e sua direção é inexorável. A roda do tempo não poderá ser parada nem revertida.

A queda é a dinâmica da escuridão moral, vivida na culpa. Ela está ligada à rapidez do movimento ( 0 avião que se aproxima) e às trevas (uma grande nuvem negra emana da cena). Não será difícil reencontrarmos aqui o mito de Faetonte, "filho do Sol, que, por ter usurpado as prerrogativas paternas, é fulminado por Zeus e depois precipitado na dura terra" (DURAND, 1998, p. 113). A imagem iconográfica exaustivamente divulgada pela mídia tem sua força não só por remeter aos milhares de mortos no atentado, mas sobretudo por ser a figuração, tão mais assustadora quanto mais histórica, das consequências nefastas que podem advir da luta humana pela verticalidade. Faetonte, na juventude, se descobre filho de Hélio, "0 deus-sol que preside ao ciclo das estações, à vegetação, à fecundação e à produtividade do solo" (BRANDÃ0, 2000, p. 227). Ao se conscientizar, pois, de seus atributos, Faetonte sai em busca de seu pai. Feliz por ver o filho, Hélio promete atender qualquer pedido seu. Faetonte, vaidoso, querendo provocar a admiração, pede para guiar o carro solar por um dia. Explica Brandão:

Seu pedido expressa o mais insensato dos projetos: alicerçado em suas próprias forças, pretende garantir ao mundo a fonte mesma de toda a luz. [...] A presunção do herói é substituir seu genitor mítico, figura imortal, porque símbolo do processo ininterrupto de iluminação e fecundação (BRANDÃO, 2000, p. 229).

A vaidade vitima Faetonte, que, incapaz de controlar os cavalos do carro-sol, é arremessado à terra, incendiado por um fogo que ele mesmo ateou. Esse mito vitaliza a fotografia do segundo avião prestes a se chocar contra as Torres Gêmeas. Se o mito de Faetonte não consegue sensibilizar quem olha a fotografia esvai-se a possibilidade do reconhecimento de que somos todos partícipes do universo retratado. A desmitologização se processa, nesse caso, pela negação do arquétipo da queda, substituído pela ideia-feita da barbárie causada por estrangeiros. 


\subsection{Einstein mostrando a língua}

Figura 3: Retrato de Einstein com a língua de fora, tirado por Arthur Sasse em 1951.

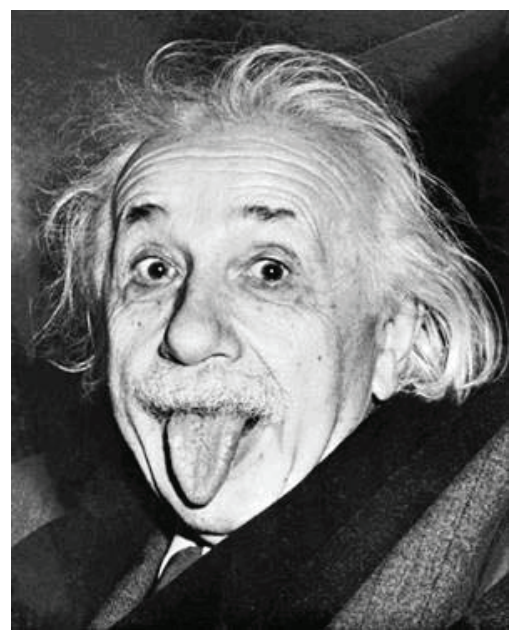

Fonte: AFP-Getty Images.

Novamente a celebridade, novamente a contradição: um respeitável homem da ciência repetindo um dos gestos favoritos das criancinhas malcriadas. 0 que poderia ser de imediato visto como insólito é, na verdade, estereotipado. Ou não é verdade que todo gênio tem de ser irreverente sob a pena de ser menos genial? No entanto, repetimos que o estereótipo, embora imagem enrijecida e, pois, com baixa pregnância simbólica, mantém um pé no arquétipo. Einstein mostrando a língua deve sua força ao arquétipo da sombra, o trickster, como chamou Jung (1995), uma espécie de Mercúrio ardiloso, malicioso e também com certa vocação de salvador. Um "bobo sábio" cuja aparição, segundo os estudos junguianos, sinaliza uma situação perigosa. É o trickster que nos faz cometer lapsos de falha, apontando para um conteúdo importante e que está sendo ignorado.

Einstein mostrando a língua pode refletir uma sombra coletiva, que ao se apresentar assim adverte para, por exemplo, os perigos de se levar a ciência - da qual o Einstein sóbrio aqui é ícone - demasiadamente a sério.

Uma das características que permitem identificar o mito de Hermes-Mercúrio é sua função de intermediário. Ela é uma espécie de denominador comum de "atributos que vão da travessia das almas ao furto, passando pelo comércio, pela magia, pela poesia e pelo saber" (FAIVRE, 2000, p. 449). De fato, é Hermes-Mercúrio que preside

[...] a revolução epistemológica de nosso tempo (ou seja, sobretudo da segunda metade do século XX), faz apelo aos intermediários, estende 0 relacional a todos os domínios da ciência e do espírito (relatividade, pluralismo, polaridades, polissemia, trocas de informação etc.), aprofunda - mais do que em qualquer época anterior - os diversos caminhos possíveis da busca interior (FAIVRE, 2000, p. 464).

A figura histórica de Einstein evoca duplamente o mito de Hermes: por ser um cientista e por ser 0 elaborador da Teoria da Relatividade. Seus estudos abalaram as noções absolutas de tempo, espaço, matéria e energia. Para ele, tempo e espaço não são separados, mas se combinam num espaço-tempo curvo. Um universo que não é plano, um tempo que não é absoluto, a curva, e não a reta, como a menor distância entre dois pontos e a matéria como uma forma de energia: não foram poucos os abalos produzidos por Einstein nas certezas vigentes. 
A desmitologização dessa imagem iconográfica se faz, como na maioria dos casos, pela sua banalização que afasta a contemplação.

Estampando capas de caderno, adesivos para carros e possivelmente servindo de inspiração para identificação visual de bandas de rock - caso dos Rolling Stones e seu álbum Forty Licks -, de tanto ser vista a língua escancarada de Einstein vai deixando de conectar o espectador com sua porção hermesiana, ambígua, relacionadora e capaz de rir da própria seriedade para se tornar, de maneira simplista, estereótipo do gênio irreverente.

\subsection{Homem enfrentando tanques de guerra na praça da Paz Celestial}

Figura 4: Em 5 de junho de 1989, durante o massacre da Paz Celestial, em Pequim, com um casaco em uma mão e um embrulho de papel na outra, um chinês anônimo se coloca diante dos blindados. Fotografia de Jeff Widener.

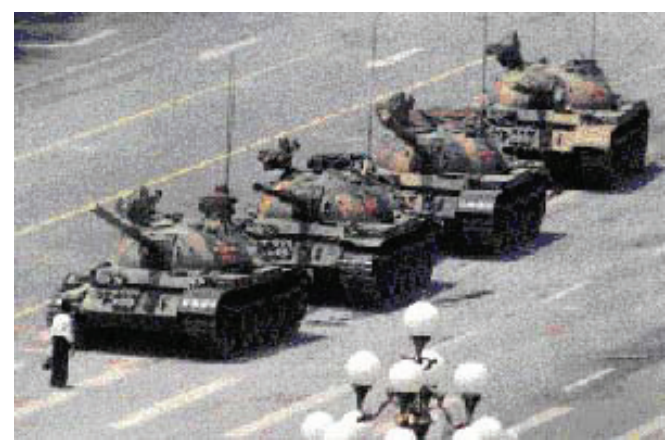

Fonte: Associated Press

A foto que se tornou representativa do massacre da Paz Celestial foi tirada no dia 05 de junho de 1989. 0 chinês anônimo, desarmado, se coloca de frente para uma fileira de tanques blindados. Estes, grandes, pesados, tentam desviar do homem que, sozinho e frágil, mas também ágil e destemido, se põe novamente à sua frente. 0 insólito balé na Avenida Chang'an ("Longa Paz") termina com o homem sendo retirado da cena e levado ninguém sabe para onde.

0 arquétipo do herói se tinge, na cena, com as cores do mito de Teseu na sua luta contra o Minotauro.

Vejamos: "minotauro", como assinala DIEL (2004), significa literalmente touro de Minos. Este último era 0 rei de Creta, que exercia uma dominação perversa sobre Atenas, impondo ao seu povo 0 pagamento de um tributo anual: sete rapazes e sete moças que deviam servir de alimento ao Minotauro. 0 Minotauro de Teseu constela com 0 tanque de guerra do anônimo chinês: ambos são monstruosamente grandes e ambos representam um poder tirânico exercido sobre um povo. Quando Teseu resolve combater o Minotauro, espera abolir a imposição tirânica, intenção simétrica à que provavelmente impulsionava 0 chinês anônimo. A simbologia dos dois episódios converge em ainda mais um ponto: Teseu embarcou para Creta junto com as vítimas que deviam ser jogadas ao Minotauro, do mesmo modo que o homem anônimo, enquanto cidadão chinês, era também vítima da rigidez do Partido Comunista.

Os mitos heroicos envolvem um período em que o herói vive na obscuridade, como uma pessoa comum, para subitamente ter revelada sua natureza diferenciada. Essa revelação ocorre através de uma ação incomum e generosa, que beneficia uma coletividade. A cena congelada 
na fotografia analisada registra essa epifania heroica, perfeitamente representada no gesto fabuloso que, se não tirou o personagem em questão do anonimato, paradoxalmente, fez com que ele fosse conhecido do mundo todo. Coerentemente com 0 arquétipo fundador, 0 heroísmo do anônimo chinês inclui o autosacrifício, a auto-doação. Seu ato pode ter-lhe trazido consequências nefastas, mas o que está em causa é o benefício da coletividade.

A estereotipia da imagem heroica se faz pela supressão justamente desse último aspecto do mito, sendo anulado o esforço de o herói realizar algo maior do que ele mesmo. Resta apenas a atuação sensacional do personagem que, no caso, é vagamente deslustrada pelo fato de ele ter desaparecido. 0 estereótipo não suporta contradições, exige a vitória sempre, ignorando que o destino de todo verdadeiro herói é a morte trágica justamente por não ser ele facilmente vencido por mortais comuns.

\section{Considerações finais}

Vimos como o estereótipo nas imagens iconográficas midiáticas é, paradoxalmente, de natureza essencialmente arquetipal, sofrendo um processo de dessimbolização até que as aparentes incoerências, que na verdade consistem em complexas coincidências de opostos, sejam suprimidas, restando apenas uma imagem que permite a rápida percepção. Essa percepção instantânea é exigência da própria aceleração do tempo, vivida na alta velocidade da tecnologia da comunicação e na consequente multiplicação das informações disponíveis - entre elas, as imagens iconográficas. A estereotipia surge, assim, como uma solução para a impossibilidade de 0 sujeito se demorar em processos cognitivos como 0 da interpretação e mesmo o da intuição (se admitirmos outra forma de acesso ao conhecimento): a interpretação é lenta porque exige o raciocínio; a intuição, apesar de se realizar num átimo, requer exercícios frequentes contemplativos, de silêncio interior.

A crescente desmitologização que leva ao estereótipo se faz pela usura do mito, seja hipertrofiando alguns de seus aspectos, seja substituindo outros por elementos estranhos ou ainda suprimindo o que não se ajusta aos papéis sociais confortados pelo ideário vigente. É assim que 0 arquétipo da feminilidade se desdobra no mito de Vênus ou da Melusina e se degrada no esterótipo da mulher bonita que tem a saia erguida pela ação do vento. De modo simétrico, 0 arquétipo do herói, convergente com o mito de Teseu enfrentando um poder tirânico se reduz a um ato espetacular do homem que paralisa uma fileira de tanques de guerra. 0 outro processo de usura do mito verificado operou pela substituição completa de uma imagem simbólica: 0 arquétipo da queda, homólogo do mito de Faetonte, teve sua natureza negada até redundar, no senso comum sobre a foto que ilustra 0 ataque às Torres Gêmeas, em barbárie, ou seja, desordem e caos provocados por estrangeiros. Vimos ainda que 0 conhecido retrato de Einstein com a língua de 
fora, bem menos do que falar de uma ciência que deve pensar sobre suas próprias sombras, pode redundar apenas na figura do gênio irreverente.

É certo que as imagens dessimbolizadas constituídas pelos estereótipos, ao mesmo tempo em que se furtam à imaginação criadora, oferecem uma chave segura para 0 entendimento, pois falam do que já se sabe. Com estereótipos, não se corre o risco de se captar a mensagem errada. Por outro lado, cabe perguntar as consequências disso no imaginário, posto que ele é atualizado a partir do processo de simbolização encetado por cada indivíduo que vai buscar, na memória coletiva, estratégias para atribuir sentido às coisas, ou seja, de enfrentamento do mundo.

A repressão da imagem mítica fornece um caminho para 0 olhar sem ver que é praticado nos nossos dias. A contemporaneidade é disfarçadamente iconoclasta porque, ao mesmo tempo em que promove a multiplicação geométrica de imagens iconográficas, mata, por sufocamento, a imagem simbólica. Encontramos imagens por toda a parte, mas só raramente nos deparamos com a imagem imaginada, aquela que é um produto direto da imaginação, que faz a riqueza do imaginário de uma época.

\section{Referências}

BARTHES, Roland. Mitologias. Rio de Janeiro:

Bertrand Editores, 1999.

BRANDÃO, Junito de Souza. Mitologia Grega - vol. III. Petrópolis: Vozes, 2000.
COELHO, Teixeira. Dicionário crítico de política cultural: cultura e imaginário. São Paulo: Fapesp; Iluminuras, 1997.

\section{DEBRAY, Régis. Vida e morte da imagem: uma}

história do olhar no ocidente. Petrópolis: Vozes, 1993.

DIEL, Paul. 0 simbolismo na mitologia grega. São

Paulo: Attar, 2004.

DURAND, Gilbert. Introduction à la mythodologie: mythes et sociétés. Paris: Albin Michel, 1996.

\section{As estruturas antropológicas do}

imaginário. São Paulo: Martins Fontes, 1998. Ciência do homem e tradição: 0 novo espírito antropológico. São Paulo: TRIOM, 2008. 0 retorno do mito: introdução à mitodologia. Mitos e sociedades. Revista FAMECOS: mídia, cultura e tecnologia, Porto Alegre, n. 1, p. 7-22, set. 2004.

FAIVRE, Antoine. Hermes. I n: BRUNEL, Pierre (org.). Dicionário de mitos literários. São Paulo: José Olympio, 2000. p. 448-466.

JUNG, Carl Gustav. Arquetipos e inconsciente colectivo. Barcelona: Paidós, 1991. et al. 0 homem e seus símbolos. Rio de Janeiro: Nova Fronteira, 1995.

LANCNER, Laurence Harf. Melusina. In: BRUNEL, Pierre (org.). Dicionário de mitos literários. São Paulo: José Olympio, 2000. p. 627-630.

LÓPEZ-PEDRAZA, Rafael. Dioniso no exílio: sobre a repressão da emoção e do corpo. São Paulo: Paulus, 2002. MACHAD0, Arlindo. A ilusão especular: introdução à fotografia. São Paulo: Funarte; Brasiliense, 1984.

PAULA CARVALHO, J. C. Energia, símbolo e magia: uma contribuição à antropologia do imaginário. 1985. Tese (Doutorado em Ciências Sociais) - Faculdade de Filosofia, Letras e Ciências Humanas, Universidade de São Paulo, São Paulo, 1985. v. 2. 
PITTA, Danielle Perin Rocha. Imaginário, cultura, comunicação. Labirinto, Porto Velho, n. 6, jan.-dez. 2004. Disponível em < http://www.cei.unir.br/artigo64. html>. Acesso em: 17 jul. 2008.

SODRÉ, Muniz. Antropológica do espelho. Petrópolis: Vozes, 2002.

WUNENBURGER, Jean-Jacques. 0 homem na era da televisão. São Paulo: Loyola, 2005 


\section{Marilyn's skirt: from the archetype to the stereotype of media imagery}

\section{Abstract}

This article develops a discussion about the nature of stereotypes in media iconographic imagery, in order to show the way they interact with the deepest layers of the imaginary, especially with archetypes and myths. The classification is made through the Regime of the Visual, proposed by Régis Debray and the theories of the imaginary by Gilbert Durand, showing that stereotype is the uppermost point in the process of symbolic impoverishment. Such impoverishment happens through the demystification of myths that have originally an oppositionist and liberating role in societies. Finally, the Durandian mythic criticism method is used to analyze four media images that remain vivid in the collective memory. The conclusion was that in their core they refer to important myths for the psychosocial balance, which were degraded by the media establishment, which resulted in the stereotypification of images that derive from the archetypes of the femininity, the fall, the trickster and the hero.

\section{Keywords}

Image. Myth. Stereotype. Media.

\section{La falda de Marilyn: del arquetipo al estereotipo en las imágenes mediáticas}

\section{Resumen}

Este artículo desarrolla una reflexión sobre la naturaleza del estereotipo en las imágenes iconográficas mediáticas con el objetivo de mostrar de qué modo ellas se relacionan con los niveles más profundos del imaginario, a saber los arquetipos y los mitos. Se utilizan la clasificación de los regímenes de la mirada hecha por Régis Debray y los presupuestos de los estudios del imaginario de Gilbert Durand, para demostrar que el estereotipo es el punto culminante de un proceso de empobrecimiento simbólico. Ese empobrecimiento sucede a través de la destrucción de mitos que, originalmente, tienen un rol de contestación y de liberación en las sociedades. Finalmente, se utiliza el método de la mitocrítica durandiana para analizar cuatro imágenes mediáticas que permanecen activas en la memoria colectiva. Se concluye que en sus bases ellas remiten a mitos importantes para el equilibrio psicosocial, pero que fueron degradados por su institucionalización en los medios de comunicación, resultando en la estereotipia de imágenes que derivan de arquetipos de la femineidad, de la caída, del trickster y del héroe.

\section{Palabras clave}

Imagen. Mito. Estereotipo. Medios de comunicación. 


\section{Expediente}

A revista E-Compós é a publicação científica em formato eletrônico da Associação Nacional dos Programas de Pós-Graduação em Comunicação (Compós). Lançada em 2004, tem como principal finalidade difundir a produção acadêmica de pesquisadores da área de Comunicação, inseridos em instituições do Brasil e do exterior.
E-COMPÓS I www.e-compos.org.br I E-ISSN 1808-2599

Revista da Associação Nacional dos Programas de Pós-Graduação em Comunicação. Brasília, v.12, n.1, jan./abr. 2009.

A identificação das edições, a partir de 2008 passa a ser volume anual com três números.

\section{CONSELHO EDITORIAL}

\section{Afonso Albuquerque}

Universidade Federal Fluminense, Brasil

Alberto Carlos Augusto Klein

Universidade Estadual de Londrina, Brasi

Alex Fernando Teixeira Primo

Universidade Federal do Rio Grande do Sul, Brasil

\section{Alfredo Vizeu}

Universidade Federal de Pernambuco, Brasil

Ana Carolina Damboriarena Escosteguy

Pontifícia Universidade Católica do Rio Grande do Sul, Bras

Ana Silvia Lopes Davi Médola

Universidade Estadual Paulista, Brasil

André Luiz Martins Lemos

Universidade Federal da Bahia, Brasil

Ângela Freire Prysthon

Universidade Federal de Pernambuco, Brasil

Antônio Fausto Neto

Universidade do Vale do Rio dos Sinos, Brasil

Antonio Carlos Hohlfeldt

Pontifícia Universidade Católica do Rio Grande do Sul, Brasil

Arlindo Ribeiro Machado

Universidade de São Paulo, Brasil

César Geraldo Guimarães

Universidade Federal de Minas Gerais, Brasil

Cristiane Freitas Gutfreind

Pontifícia Universidade Católica do Rio Grande do Sul, Brasil

Denilson Lopes

Universidade Federal do Rio de Janeiro, Brasil

Eduardo Peñuela Cañizal

Universidade Paulista, Brasi

Erick Felinto de Oliveira

Universidade do Estado do Rio de Janeiro, Brasil

Francisco Menezes Martins

Universidade Tuiuti do Paraná, Brasil

Gelson Santana

Universidade Anhembi/Morumbi, Brasi

Hector Ospina

Universidad de Manizales, Colômbia

leda Tucherman

Universidade Federal do Rio de Janeiro, Brasil

Itania Maria Mota Gomes

Universidade Federal da Bahia, Brasil

Janice Caiafa

Universidade Federal do Rio de Janeiro, Brasil

Jeder Silveira Janotti Junior

Universidade Federal da Bahia, Brasil

\section{João Freire Filho}

Universidade Federal do Rio de Janeiro, Brasil

John DH Downing

University of Texas at Austin, Estados Unidos

José Luiz Aidar Prado

Pontifícia Universidade Católica de São Paulo, Brasil

José Luiz Warren Jardim Gomes Braga

Universidade do Vale do Rio dos Sinos, Brasil

Juremir Machado da Silva

Pontifícia Universidade Católica do Rio Grande do Sul, Brasil

Lorraine Leu

University of Bristol, Grã-Bretanha

Luiz Claudio Martino

Universidade de Brasília, Brasil

Maria Immacolata Vassallo de Lopes

Universidade de São Paulo, Brasil

Maria Lucia Santaella

Pontifícia Universidade Católica de São Paulo, Brasil

Mauro Pereira Porto

Tulane University, Estados Unidos

Muniz Sodre de Araujo Cabral

Universidade Federal do Rio de Janeiro, Brasil

Nilda Aparecida Jacks

Universidade Federal do Rio Grande do Sul, Brasil

Paulo Roberto Gibaldi Vaz

Universidade Federal do Rio de Janeiro, Brasil

Renato Cordeiro Gomes

Pontifícia Universidade Católica do Rio de Janeiro, Brasil

Ronaldo George Hela

Universidade do Estado do Rio de Janeiro, Brasil

Rosana de Lima Soares

Universidade de São Paulo, Brasil

Rossana Reguillo

Instituto Tecnológico y de Estudios Superiores do Occidente, México

Rousiley Celi Moreira Maia

Universidade Federal de Minas Gerais, Brasil

Sebastião Carlos de Morais Squirra

Universidade Metodista de São Paulo, Brasi

Simone Maria Andrade Pereira de Sá

Universidade Federal Fluminense, Brasil

Suzete Venturelli

Universidade de Brasília, Brasil

Valério Cruz Brittos

Universidade do Vale do Rio dos Sinos, Brasil

Veneza Mayora Ronsini

Universidade Federal de Santa Maria, Brasil

Vera Regina Veiga França

Universidade Federal de Minas Gerais, Brasil
COMISSÃO EDITORIAL

Ana Gruszynski I Universidade Federal do Rio Grande do Sul, Brasil

Rose Melo Rocha I Escola Superior de Propaganda e Marketing, Brasil

CONSULTORES AD HOC

Alberto Schneider I Visitante Tokyo University

Alexandre Rocha da Silva I Universidade Federal do Rio Grande do Sul, Brasil

Fernanda Bruno I Universidade Federal do Rio de Janeiro, Brasil

Ida Stumpf I Universidade Federal do Rio Grande do Sul, Brasil

Kati Caetano I Universidade Tuiuti do Paraná, Brasil

Laura Cánepa I Universidade Anhembi Morumbi, Brasi

Malena Contrera I Universidade Paulista, Brasil

Sandra Gonçalves I Universidade Federal do Rio Grande do Sul, Brasil

Vicente Gosciola I Universidade Anhembi Morumbi, Brasil

REVISÃO DE TEXTO E TRADUÇÃO I Everton Cardoso

EDITORAÇ̃̃o ELETRÔNICA I Raquel Castedo
COMPós I www.compos.org.br

Associação Nacional dos Programas de Pós-Graduação em Comunicação

Presidente

Erick Felinto de Oliveira

Universidade do Estado do Rio de Janeiro, Brasil erickfelinto@uol.com.br

Vice-presidente

Ana Silvia Lopes Davi Médola

Universidade Estadual Paulista, Brasil

asilvia@faac.unesp.br

Secretária-Geral

Denize Correa Araújo

Universidade Tuiuti do Paraná, Brasil

denizearaujo@hotmail.com 